\title{
NEIGHBOURHOOD AND PERCEPTIONS IN SMALL CITIES ON DIFFERENT RUSSIAN BORDERS
}

\begin{abstract}
National neighbourhood have a significant influence on the life of people living along the state borders. They shape human interactions across borders and border residents' attitude towards neighbours. Many concepts like 'neighbourhood,' 'proximity,',trust', '(un)familiarity', and 'otherness' are usually used to explain this processes in border studies. However, insufficient attention has been paid to the comparing of perceptions, life strategies and everyday life of borderland population depends on neighbouring policy, border regime and neighbourship. Here we focus on different Russian borders with Ukraine (the new contested border in Crimea), Kazakhstan (the EAEU's internal border), and China (old international and contact border) using different sources of information, including expert interviews as well as field observations and focus groups conducted with locals. We find that people differentiate between the neighbors they know and the neighbouring state they do not trust. Significant differences between neighbouring territories, unfamiliarity, and otherness are not allowed to get in the way of contact, because it is this contact that allows local residents to make a living. In conclusion, our results suggest that while the objective differences between the various sections of Russian borders serve to diversify the neighbourhood situations, their subjective perceptions and social representations serve to unite them.
\end{abstract}

KEY WORDS: border, border regions, neighbourhood, everyday life, perceptions, Russian borderland

CITATION: Maria V. Zotova and Anton A. Gritsenko (2020) Neighbourhood And Perceptions In Small Cities On Different Russian Borders. Geography, Environment, Sustainability, Vol.13, No 1, p. 64-73

DOI-10.24057/2071-9388-2019-124

\section{INTRODUCTION}

In recent decades, state borders have attracted the close attention of scholars from around the world. Initially, such scholars' research was focused on interaction, cross-border cooperation, and the flow of people, goods, ideas, and information across borders, but it has subsequently seen a gradual shift from examining borders per se to considering the processes of bordering and othering (Brambilla 2015; Newman and Paasi 1998) - in other words, scholarship has turned its attention from territorial to social and political functions. Despite this shift, borderlands as contact zones - with intensive international exchanges, social and political encounters and contradictions, mutual transitions, and manifestations of differences - remain a key locus for the investigation of multidimensional and multiscale border phenomena. The interest in borderlands and border practices is thus oriented to (re)structuring social and political spaces, and shaping people's identities and everyday life, across multiple borders created by diverse actors. It is also bound up with the search for answers to a number of fundamental questions raised in various aspects by F. Bart, G. Simmel, M. Foucault, B. Anderson, and others, namely: how do social and political borders relate to each other, and what role do they play in our lives, activities, and social and political relations? The overlapping interests of nation-states and the inhabitants of borderlands results in an ambiguity surrounding the processes taking place at the border, where rivalry enforces cooperation, which proceeds 'over the barriers' (Vendina et al. 2007; Brazhalovich et al. 2017). This highlights the necessity of understanding what borders mean to people and how borderrelated practices affect societies in general. Recent debates on borders have devoted considerable attention to the everyday life of people living in borderlands, their personal motives for crossing borders, and their perceptions of neighbours (Van der Velde et al. 2008; Helleiner 2009; Aure 2011; Ghosh 2011; Balogh 2013; Stoklosa 2013; Domaniewski et al. 2016; Laine 2016). However, comparative questions concerning territorial differences and their consequences for local life mostly remain beyond the scope of such studies, despite the fact that various borders and border regimes create different challenges for people, their well-being, and the possibility of cross-border activities. This paper aims to fill this significant gap in research by exploring and discussing the social function of neighbourhood and borders in a variety of small shrinking cities at different points along the Russian border. First, we begin by sketching the theoretical framework underpinning our study. Then we will consider how people perceive neighbouring states and neighbours, and what they mean for them. Following this, we will turn analyse what people associate with border regimes, how often and why they cross the border, and what they face when they do. Finally, we will discuss the indirect effect of the border and neighbourhood by considering the opportunities, hopes, and expectations of people living at the border.

\section{THEORETICAL FRAMEWORK}

A variety of concepts in border studies have been used to explain human interactions across borders and border residents' attitude towards neighbours.

The concepts of proximity and distance addresses to the formation of social ties, solidarity, and identity upon the influence of interaction across the border (Szytniewski et al. 2017). As noted by (Trippl 2010), (Boschma 2005), (Torre and Rallet 2005), geographical proximity alone is neither necessary nor sufficient to facilitate the formation of social ties. Consequently, frequent social and cultural encounters can generate feelings of familiarity, recognition, and security (Van Houtum 1999). However, when cultural differences are too great, people may not be able 
to make sense of them when using existing knowledge and representations of otherness; they will eventually experience discomfort (Szytniewski et al. 2017). Proximity and distance are also associated with the character of functional connectivity and accessibility, related to cross-border institutes and activities, and not to the geographical location alone (Schack 2001).

The concept of trust is often used in the contexts of transnational relation, cooperation, and human interactions. Social capital is an important element of cross-border networking and regional integration (Koch 2018). Trust of neighbours is especially important both in cooperation and in establishing informal ties, because it contributes to overcoming differences including territorial tensions. On the grassroots level, social integration occurs easily between neighbours with higher levels of trust (Rippl et al. 2009). A good example of this is found in territories with long-term coexistence within a single country where the ability of people to communicate and understand each other is based upon common values, language, and identity, as well as upon similarities in physical surroundings and daily routine.

To better understand cross-border (im)mobility Spierings and van der Velde (2008) have proposed the concept of (un) familiarity. It suggests that borders could in fact promote mobility due to the functional, physical, and socio-cultural differences between places. Depending on how people perceive differences between countries, they either stay at home or visit the other side (Spierings and van der Velde 2013). On the one hand, dissimilarities between 'here' and 'here', and the uniqueness of foreign places could lead to border-crossing for a variety of purposes (tourism, leisure, shopping etc.) (Spierings and van der Velde 2008). When the 'unfamiliarity' of a place dissolves, its attractiveness to visitors from abroad may also disappear (Timothy 1995). On the other hand, large dissimilarities in the socio-cultural sense will result in mental borders that have a negative impact on cross-border interactions (Van Houtum 1999). When dissimilarities between places on each side of the border are too large, they could restrain people from making the cross-border trip (Szytniewski and Spierings 2014).

Another theoretical construction proposed by Dolińska and Niedźwiecka-Iwańczak (2017) is based on George Simmel's concept of 'strangeness'. It references to the dichotomy of 'Insiders' and 'Outsiders', with the division of the latter into 'Strangers' and 'Others'. While a 'Stranger' is currently, or potentially, dangerous, and poses a threat to values that an individual holds dear, the 'Other' is one whom we do not understand and thus do not accept at all (Kozera 1999), as he/ she is not an 'Insider'. In the process of structuring the social world, otherness may remain just otherness, but it may also turn into strangeness. The perception of individuals and groups as other, dissimilar, or different from us does not necessarily trigger any form of strangeness if it is limited to giving facts and does not engage in evaluation. The awareness of otherness turns into strangeness only when the perceived dissimilarity is combined with negative emotions and attitudes.

In our study, we apply all these concepts to interpret the setting of living on the border of a different neighbourhood. We proceed from the understanding of neighbourhood as not only top-down geopolitical imaginaries and everyday perceptions and representations (Scott et al. 2019) but also as differences between places, including socio-economical, cultural, and institutional contrasts, among others.

\section{CASE STUDIES}

To remove the need to consider territorial proximity and to clarify the role of other border-related factors constituting personal life strategies, cross-border practices and perceptions we decided to focus on the Russian border cities, because they function as important economic centers for border areas and in particularly for social activities and cross-border cooperation. In Russia, there are only 17 such cities. Some of them are rather big and diverse. We focused on such of them that have similar socioeconomic conditions and problems of urban development that make them more available for comparative analysis and reflecting geopolitical and territorial factors of neighbourhood. We selected three sections of the Russian border that differ in age and origin, regimes and socio-economic contrasts across the border. The first one is new conflict international border in Northern Crimea, contested by Ukraine and unrecognized by the international community. It appeared after the annexation of Crimea to Russia in 2014, and is characterized by a strict border crossing regime. Before 1954 there was a border between Russian and Ukrainian Soviet Republics. Then it existed as administrative boundary of Crimean autonomy in Ukraine. The second one is the internal border of the Eurasian Economic Union (EAEU) between Russia and Kazakhstan. Before the collapse of the USSR, the border was also administrative and completely open as in Crimea, binding together different territories of a single state. Finally, the third section is old border between Russia and China, that was highly militarized and closed during the Soviet time. Today it is much more open and contact, while it is dividing too different cultural worlds.

Thus, we selected four small cities on these sections of Russian border. Despite of mentioned similarities they have certain specific of historical and cultural development that define some features of social, economic and cross-border activities. Two cities are in Northern Crimea, close to the new contested border: Armyansk (population 22,000, located $5 \mathrm{~km}$ from the border) and Dzhankoy (population 39,000, located $40 \mathrm{~km}$ from the border). Armyansk is a mono-industrial city. Its defining chemical enterprise 'Crimean Titan' provides employment for almost half the local population. Dzhankoy, by contrast, is ex-industrial and now a principally commercial city, having mutual links with surrounding agricultural areas. Before the border appeared, it was also a transport hub connecting Crimea with Ukraine and Russia by roads and railways. Many locals found jobs servicing traffic flows. Since 2014, however, Crimea has experienced the shock of huge changes caused by the transition to the Russian legal and institutional field, a break almost all its old supply chains and economic ties with Ukraine, an energy, water and transport blockade, and international sanctions. These have undermined the stability of many Crimean enterprises, some of which have had to close. 'Crimean Titan' began to experience interruptions in its supply of raw materials and was forced to cut staff. The Dzhankoy transport hub has become into a transport dead end (Fig. 1), and agricultural enterprises have been forced to change their specialization due to lack of water.

The next city, Troitsk (population 75,000, located $11 \mathrm{~km}$ from the border with Kazakhstan) like the border itself, has experienced frequent changes in its territorial functions. For a long time it was a prosperous trading and cultural center on the routes between Russia, China, and Central Asia. During the 19th century Troitsk became the jewel of architecture in the South Urals due to the construction of various attractive public buildings, banks, and trade houses (Fig. 2). In the Soviet period, it received a diverse industrial development, enjoyed extensive cooperative ties with Kazakhstan, and was the leading Russian centre for the Virgin Lands campaign. After the collapse of the USSR, 8 of the 12 large enterprises were closed and the city ended up on the state border, the ethno-cultural contrasts of which gradually grew with the national state-building agendas in Russia and Kazakhstan. De-bordering processes were launched only in the 2010s with the implementation of Eurasian integration initiatives. The city nowadays has a development deficit, and decline and outflow of population. 


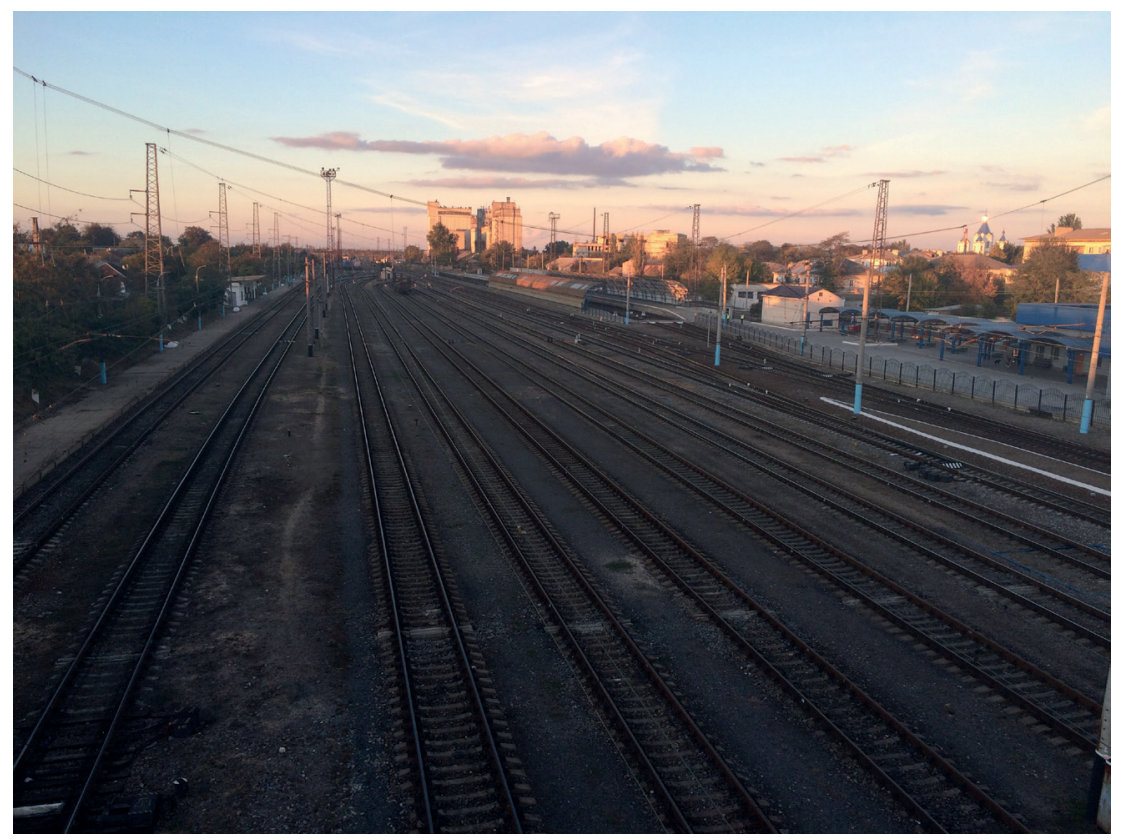

Fig. 1. Dzhankoy railway station lies deserted following the events of 2014

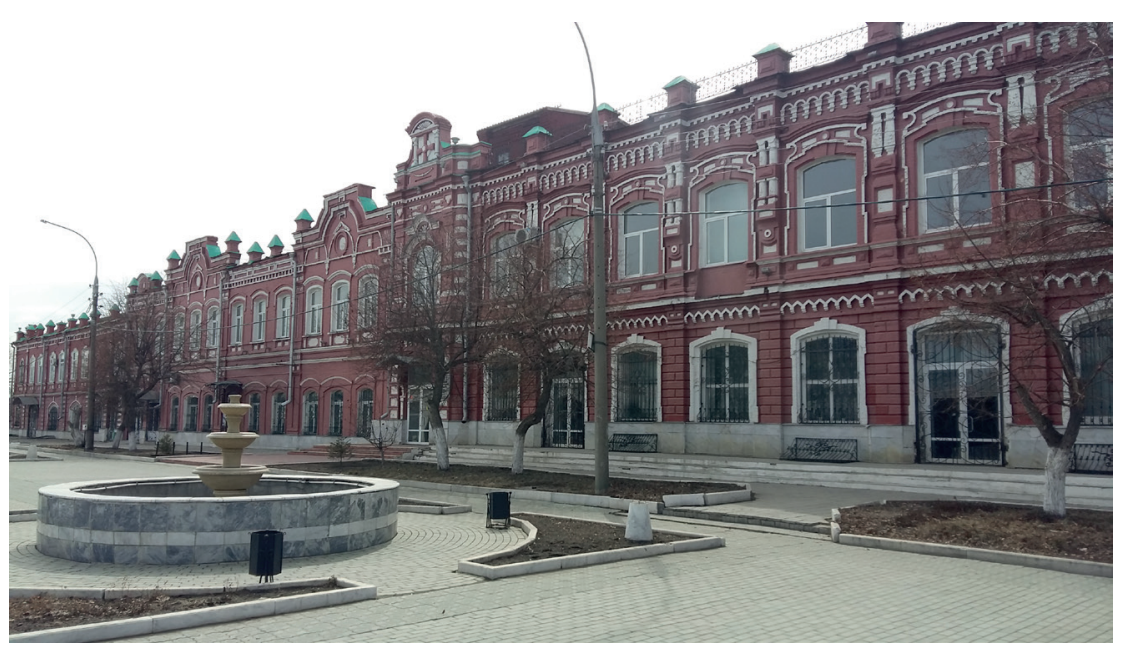

Fig. 2. Historical building of trade house in pseudo-Russian style (1870). Nowadays it is a branch of the Chelyabinsk State University in Troitsk

Finally, Zabaikalsk (population 13,000, located 5 km from the border) is a small town (Fig. 3) on the Chinese Eastern Railway station with container terminal nowadays serving $60 \%$ of the traffic between Russia and China, and the largest checkpoint, passing more than one million people annually. Changing the border regime entailed a restructuring of the local economy in Zabaikalsk towards management of the border, border crossings, and transit flows.

Peripherality, limited economic development, and negative demographic processes make the life of each of these cities highly dependent on external impulses, including changes of neighbourhood relations and crossborder interactions.

\section{RESEARCH METHODS}

We conducted our research into these Russian border cities using various sources of information and methods of analysis. On the one hand, we used official documents of territorial development and data (e.g., border crossing, economic, and demographic statistics); on the other hand, we relied on interviews with local and regional experts field observations, and focus groups with locals.

We considered focus groups as the most relevant method for gathering and analyzing grassroots information due to its flexibility and adaptability both in terms of the composition of groups and in terms of the non-standard conditions of communication. Between autumn 2017 and spring 2018, 13 focus groups were consulted: four in Dzhankoy, five in Troitsk, and two each in Armyansk and Zabaikalsk. The number of groups in each located varied due to population size and the poly/mono-functionality of the cities. The initial condition for participant selection was that we focus on the most representative groups of the urban population, not exclusively those people involved in cross-border activity. We proposed that even if a person does not actively participate in cross-border movement, exchange, and communication, the border nonetheless affects his life through his relatives, friends, shopping, fashion, ideas, fears, and expectations. Much attention was paid to the dominant cohorts among the economically active part of the population aged 3050 years. Employment in different spheres of activity, and differences in income, social status, and ethnicity were also taken into account in the selection process.

The recruitment of respondents was carried out by professional recruiters using the 'snowball' method. The selection of focus group participants was conducted at the second stage, in which files of potential respondents were screened under the proposed selection criteria: age, professional activities and ethnic self-identification. All 
focus groups have included ethnic minorities that play a significant role in the cities and have a particular symbolic capital because they also represent title ethnic group of neighboring country (except for Chinese).

The composition of focus groups was the following: in Armyansk, the group consisted of factory workers and local entrepreneurs; in Dzhankoy, groups contained state employees, pensioners, local entrepreneurs, and a mixed group with local Ukrainians and Crimean Tatars; in Troitsk, the groups contained state employees, pensioners, local entrepreneurs, factory workers, and management staff; finally, in Zabaikalsk, the group consisted of state employees and local entrepreneurs. All group discussions were held using a single but flexible guide, which included the following research topics: images of Russia and the neighbouring state, current relations between states, border-related practices and cross-border mobility, interactions between people in a multi-ethnic environment and across the border, perceptions of the border, and welfare and specifics of everyday life. Projective questioning techniques (e.g., standard methods of associations, combinations, metaphorization, semantic attribution, etc.) were actively combined. However, this combination differed in our cases studies. For example, in Crimean cities we don't use semantic test, when people gave characteristics for the most authoritative local ethnic groups, which they defined themselves. It was replaced by modelling of abstract dialogs, disclosing relationships between them.

\section{RESULTS}

Since state borders are both symbols of social institutions and power relations (Newman et al. 1998), the competition for the constitution of'reality' and for the meanings of borders and neighbourhood occurs in the borderlands. Ideas about neighbours are defined from above through socialization, interstate relations, and management of public opinion, but they are also shaped in everyday border-related practices (Dolińska et al. 2017).

\section{Images of neighbours.}

Discussing neighbouring countries, participants distinguish two ideas: the first is that the neighbouring country is 'a state and government', and the second is that it is 'a country and people'. Concerning the first category, participants expressed various but mostly negative emotions, ranging from mistrust to hate and fear, while concerning the second category, participants tended to express positive emotions such as sympathy and trust.
Individual opinions concerning neighbouring countries and argumentation demonstrated a certain proximity to the official political discourse in Russia. Thus, in Northern Crimea, Ukraine is perceived as a hostile and threatening state with many internal problems and a bad international reputation. In Troitsk, Kazakhstan is considered a friendly country, which nonetheless suffers from ethnonationalism: respondents often noted that in Kazakhstan the rights of Russian-speaking citizens are regularly violated. In Zabaikalsk, the attitude towards neighbours is more ambivalent. China is perceived as a strong partner country. However, the participants did not have full confidence in China, and believed Russia should not rely on it. This corresponds with the skepticism to China widely found in mass media (Kolosov et al. 2019).

In contrast to this attitude towards the neighbouring states, attitudes towards the actual people living on the other side of the border were very different. Respondents associated them with cross-border practices and special trust in relationships that, according to recent studies (Zotova et al. 2018), are widespread in almost all sections of the Russian border. On the new post-Soviet borders, their existence is largely based on the long-term coexistence of people within a single country that ensured fluency in the Russian language, fostered ethno-cultural exchanges and mutual influences, and promoted common values, as well as shaping mixed or dual cultural identities on both sides of the border. Family ties, professional networks, and friendships between people from neighbouring regions have persisted to the present day. Today this allows people to communicate across the border and understand each other without any difficulty. Tests and abstract dialogues in which participants identified the characteristics for key ethnic groups of residents showed that people in Crimea hardly at all distinguish a difference between Russians and Ukrainians. Common opinion of respondents were the following: «We do not know who are Ukrainians there», «Nobody ask who is Ukrainian, and who is Russian», «We are not distinguish Russians and Ukrainians, we live there all together», «There is no difference, we are the same».

On the border of Kazakhstan people also hardly draw a distinction between Russians and Kazakhs. In fact, most of the characteristics ascribed to Russians and Kazakhs were absolutely the same (Table 1). Participants recognized that in many cases, local residents do not see a difference between people on either side of the border, and cannot identify, for example, those who came to the city from the nearest areas of the neighbouring state. However, they do feel some differences from people from other regions of Russia and

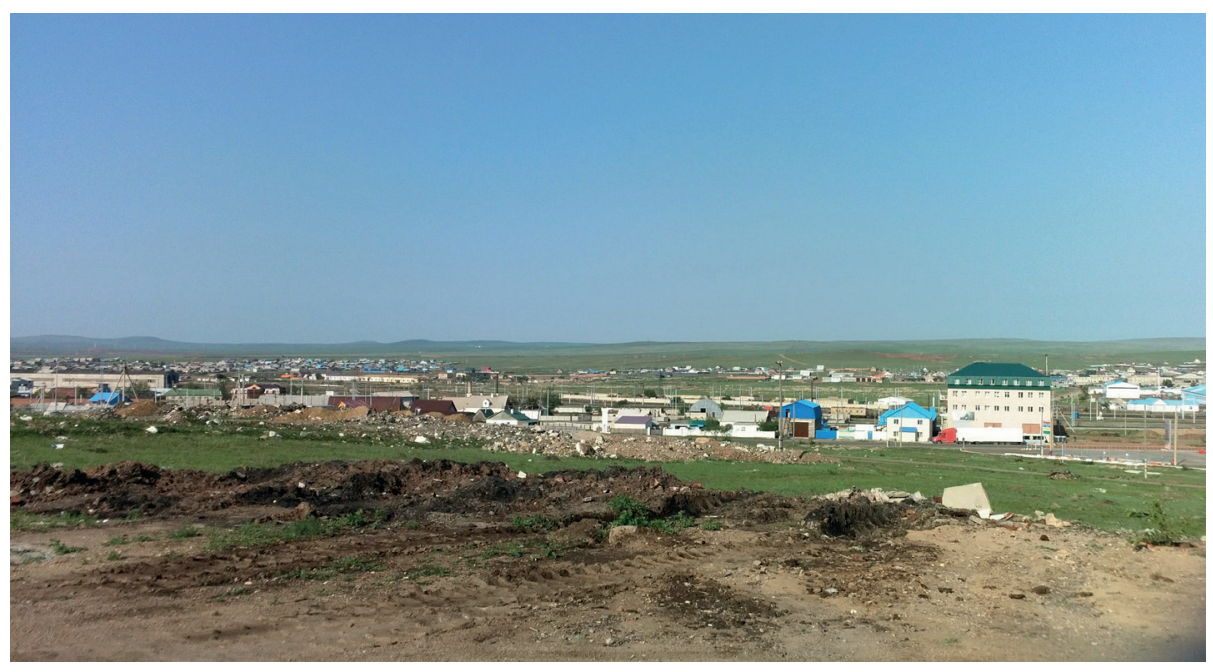

Fig. 3. Zabaikalsk with skyscrapers of neighbouring Manzhouli in the background 
sometimes even from own region (from Southern Crimea in Armyansk and Dzhankoy; from the north of Chelyabinsk region in Troitsk; from Chita in Zabaikalsk). Difficulties in interacting and mutual understanding, as participants noted, only exist with migrants from South Caucasian and Central Asian countries. They are usually perceived as 'strangers' who pose a potential threat. In Crimea, Crimean Tatars often play such a role, while in Troitsk and Zabaikalsk it is Azerbaijanis, Uzbeks, etc, who are seen as 'strangers'. They were mostly endowed with negative characteristics. In certain situations they oppose them to dominant Russians. In all the cities self-images of Russians fully coincided with images conducted by mass opinion surveys of Russian leading sociological agencies.

At the Russian-Chinese border the situation appears differently. The limited list of characteristics given to Chinese suggests that citizens of the neighbouring state are poorly known; apparently they are excluded from the 'we-community' and play the role of 'others'. However, as shown in Table 2, less frequent encounters leads to a reduced familiarity. In Troitsk the image of Chinese people is more blurred; local experience of interaction was limited to the passive observation of Chinese workers employed in the construction of a new energy unit for the local power plant over two years. In Zabaikalsk, by contrast, local people communicate frequently and regularly with neighbours due to cross-border trips and shuttle trading. However, as almost no one in Zabaikalsk speaks Chinese such communication takes place in pidgin. It is enough for transactions, but not for genuine understanding. Therefore, knowledge about the neighbouring country and familiarity with its culture including social norms and symbolic values — is reduced to stereotypes and is prevented from reaching any higher level of interaction.

\section{Perceptions of the border and border regime}

The dual perception of neighbouring countries as both 'a state and government' and 'a country and people' is reflected in the dual meaning of borders, which impact on the perception of border regimes. Thus, both the contact and barrier functions of a border can be viewed differently from each angle.
During focus groups we posed the question: 'What would happen if the border were to be fully opened/closed?' (Table 3). In all cases, the participants emphasized that the border with the neighbouring country is needed. Even if the relationship between states seems friendly for now, the border could not be fully opened because it provides peace and stability, and protects against negative influences from the outside (drug traffic, smuggling, etc.). The border is perceived as a symbol of the state and protection from 'chaos' and 'disorder', as well as a guarantee of personal security. On the other hand, the order and wellbeing of everyday life are also closely linked with the border regime. Nobody even could imagine the full closure of the border. Communication between relatives and friends, cross-border trade and other activities (like shopping, leisure, tourism, labor, education, etc.) motivated by territorial proximity to the neighbouring country and its markets were the most popular arguments for such a view. Thus, the attitude of the local community to the possible openness of the border explains their perception of state function: that the border is necessary for reasons of state stability and security. In turn, discussion of its full closure reflects their perception of their relationship to neighbours, from whom they could not imagine being fully separated.

If in Armyansk, Dzhankoy, and Troitsk, the respondents noted that the current state of the border mainly impedes upon family ties, in Zabaikalsk it helps them 'survive'. These varied opinions reflect differences in what local people value and confront on a daily basis. Our case studies allow us to understand what constitutes the differences and how cross-border communication is affected by differences in border regimes and neighbourships.

\section{Border as obstacle}

The contested status of the new international border in Crimea has hampered communication across it. Residents of Crimea may cross the border only by driving, in a car with Ukrainian number plates, and with a Ukrainian passport that they are allowed to keep. Border crossing by cars with Russian number plates is not permitted due to sanctions on the Ukrainian side. To cross the border by public transport is also impossible; regular buses and trains

Table 1. Characteristics given to Russians and Kazakhs in Troitsk

\begin{tabular}{|c|c|c|c|}
\hline \multicolumn{2}{|c|}{ Positive } & \multicolumn{2}{|c|}{ Negative } \\
\hline Kazakhs & Russians & Kazakhs & Russians \\
\hline $\begin{array}{c}\text { Brave } \\
\text { Cultural (3) } \\
\text { Generous } \\
\text { Hardworking } \\
\text { Loving (3) } \\
\text { Sincere (2) } \\
\text { Open } \\
\text { Rational } \\
\text { Respectful to elders (2) } \\
\text { Simple (2) } \\
\text { Smart } \\
\text { Traditional } \\
\text { Peace-loving (2) } \\
\text { Hospitable (2) }\end{array}$ & $\begin{array}{c}\text { Brave (4) } \\
\text { Cultural } \\
\text { Generous (2) } \\
\text { Hardworking } \\
\text { Loving (2) } \\
\text { Sincere (2) } \\
\text { Open (3) } \\
\text { Rational } \\
\text { Respectful to elders } \\
\text { Simple (2) } \\
\text { Smart (3) } \\
\text { Traditional } \\
\text { Advanced (4) } \\
\text { Energetic } \\
\text { Good (4) } \\
\text { Patient (3) } \\
\text { Patriotic (4) }\end{array}$ & $\begin{array}{c}\text { Arrogant (2) } \\
\text { Retarded (2) } \\
\text { Stupid } \\
\text { Evil } \\
\text { Lazy } \\
\text { Secretive } \\
\text { Cowardly } \\
\text { Power-hungry }\end{array}$ & $\begin{array}{c}\text { Arrogant } \\
\text { Retarded (2) } \\
\text { Stupid (3) } \\
\text { Evil (2) } \\
\text { Lazy (2) } \\
\text { Secretive } \\
\text { Cowardly }\end{array}$ \\
\hline
\end{tabular}

Note: Numbers in brackets indicate the number of identical answers given by focus group participants during the test. 
Table 2. Characteristics given to Chinese in Zabaikalsk and Troitsk

\begin{tabular}{|c|c|c|c|}
\hline \multicolumn{2}{|c|}{ Positive } & \multicolumn{2}{|c|}{ Negative } \\
\hline Zabaikalsk & Troitsk & Zabaikalsk & Troitsk \\
\hline Hardworking (2) & Hardworking (2) & Arrogant & Underdeveloped \\
Energetic & Clever & Evil \\
Rational & & Stupid & \\
Loving & & Secretive & \\
& & Cowardly & \\
\hline
\end{tabular}

Note: Numbers in brackets indicate the number of identical answers given by focus group participants during the test.

connecting Crimea with Ukraine have been cancelled. At the border, meticulous, picky, and sometimes humiliating document and baggage checks denigrate individuals. Due to the established border regime, people have lost the opportunity to consume familiar Ukrainian products and goods. Russian customs officers confiscate all food and other Ukrainian goods prohibited for import. Moreover, inhabitants of Armyansk and Dzhankoy crossing the border often encounter misunderstanding and even hostility at Ukrainian checkpoints, as well as on the other side of the border, due to their support for the annexation of Crimea in the referendum in March 2014. Therefore, they significantly cut their trips and travel to Ukraine only in order to visit relatives. Citizens of neighbouring Ukrainian regions have also reduced the frequency of cross-border visits. During the period 2014-2017, the number of border crossing in the north of Crimea (checkpoints Kalanchak, Chaplinka and Chongar) fell from 3.6 to 2.5 million people. Ukrainians visit Crimea mostly for tourism and family visits. During these contacts, many people are careful not to mention political issues anymore, while others have simply fallen out of touch with friends and family across the border. In either case, relations have become tenser and less trusting.

The main barriers to crossing the Kazakhstan border are the large distances between cities and the undeveloped and overloaded checkpoints, rather than the border itself. For citizens of neighbouring countries, the border crossing procedure is simplified, and people are allowed to use internal identity documents. Six buses and two trains daily connect Troitsk with Kostanay, Zhitikara, and Rudnyy across the border. Every year, more than two million people cross the border in Troitsk, and a quarter of them are citizens of Kazakhstan. The traffic flow grew twice after the cancelation of customs in 2010. The most popular reasons for crossing are to visit relatives and friends, diversify consumption, and save on goods purchases (sausages, sweets, vodka, and other products are cheaper in Kazakhstan). Economic crises and devaluation of ruble in the end of 2014 contemporary increased flow of people across the border in 1.5 times due to migrants from Kazakhstan. However, the situation return to pre-crisis level up to 2017.

The Russian-Chinese border opened to the movement of people in the early 1990s. Those wishing to visit the neighbouring country needed to have received an appropriate visa through national consulates located in several large cities. The closest such consulate to Zabaikalsk was found in Khabarovsk, $2500 \mathrm{~km}$ away (1.5 to 2 days of travel). The impressive demand for cheap Chinese goods in Russia has intensified shuttle trade at the local level that has dramatically increased the flow of people and goods across the border. In the 2000s, China initiated a number of programs for the development of its northern border territories. As a result, Russian citizens received the opportunity to acquire visas at the border, and could easily visit certain adjacent cities in small groups. The traffic flow highly increased up to one million people per year. Manzhouli, located on the border just opposite Zabaikalsk, was one such city; nowadays the two cities are closely connected through transport links, with more than ten buses daily running between them.

Table 3. Responses to the question 'What would happen if the border were to be fully opened/closed?'

\begin{tabular}{|c|c|c|}
\hline City & 'If the border were to be fully opened' & 'If the border were to be fully closed' \\
\hline Armyansk & $\begin{array}{l}\text { «f they [certain citizens of Ukraine] come here, it will } \\
\text { be worse than in Donbass» }\end{array}$ & $\begin{array}{l}\text { «t is unacceptable. This will create discontent. We have } \\
\text { family ties. We are deeply connected with each other» }\end{array}$ \\
\hline Dzhankoy & $\begin{array}{c}\text { "lt will be a mess and chaos. Lawlessness»; «Certain } \\
\text { groups will immediately come here from Ukraine, and } \\
\text { this will lead to great bloodshed. They will twist our } \\
\text { heads off» }\end{array}$ & $\begin{array}{c}\text { «I's impossible»; «lt cannot be closed»; «lt complicates } \\
\text { our relationships with relatives» }\end{array}$ \\
\hline Troitsk & $\begin{array}{l}\text { «The border is needed because we do not know } \\
\text { what may happen tomorrow»; «We still need to keep } \\
\text { the gunpowder dry. We cannot open the border } \\
\text { absolutely»; "Kazakhstan, of course... friends, but all } \\
\text { could turn. Today we are friends, but tomorrow?... With } \\
\text { Ukraine, too, ... that is how it turned out...» }\end{array}$ & $\begin{array}{l}\text { "lt is impossible in any case. We need to cooperate, } \\
\text { communicate, trade, we need a dialogue of cultures»; } \\
\text { "lt's scary because we have families, relatives, etc.» }\end{array}$ \\
\hline Zabaikalsk & $\begin{array}{c}\text { "lt will be disorder», «All the Chinese will come here. } \\
\text { They will take away all our land»; "If there is no border, } \\
\text { there will be no Russians here. Only the Chinese will } \\
\text { stay» }\end{array}$ & $\begin{array}{c}\text { "Close the border and immediately there will be no one } \\
{[\text { left] here... Thanks to the border, people live here»; «We }} \\
\text { need the border to survive» }\end{array}$ \\
\hline
\end{tabular}




\section{Border as resource}

A border also of course has several indirect effects on life in border regions that local people do not perceive and explicitly articulate.

The new contested border in Crimea has led to the sharp reduction of external economic relations, as well as property redistribution, reorganization, and instability of local enterprises (especially 'Crimean Titan' and 'Dzhankoy Railway Station'). At the same time, the hardship of transition was partly offset by new economic opportunities. A decrease in economic competition on the local market due to disappearing of Ukrainian products and distributers, for example, allowed local farms to emerged from the shadow and to be legalized, and intensify production. Russian social and economic transfers leaded to wage, pensions and social benefits growth, as well as infrastructural investments. The deployment of Russian military garrisons, customs, and border control provided new jobs, along with additional demand for housing, value-added goods, and services.

Thus, people and local enterprises have faced big challenges since the border emerged. But, on the other hand, they also have felt positive changes comparing current state with Ukrainian period when Northern Crimea did not received enough investments in infrastructure and city development. As noted by respondents, during that time local people feel themselves in some way as neglected by Ukrainian authorities.

The economic crisis of the 1990s, the establishment of the state border, and to related rupture of industrial ties with Northern Kazakhstan had resulted in the closure of eight large enterprises and a change in city functions. The emergence of customs and border services, together with cross-border trade and smuggling, can only partially compensate the loss of employment and income for many locals. Integration initiatives in the framework of the EAEU, creating a single labour market have not yet brought new employment prospects. On the contrary, some border services - for example, customs posts - have been abolished. The small contrast in living standards and prices could not stimulate cross-border mobility and shuttle trade. However, Troitsk was able to sustain its central function for Russians pushed from the neighbouring territories of Kazakhstan because of an active nation-building process there. Despite the growth of peripherality of Troitsk, it has retained its cultural capacity for surrounding territories, becoming one of the terminal centers for Kazakhstan citizens seeking a place to live, work, and pursue educational opportunities. If the immigration flow into Troitsk from the neighbouring country has declined significantly in recent years, the flow of other migrants has slightly increased.

The opening of the Russian-Chinese border was accompanied by its demilitarization, and, as a result, a reduction in military garrisons and the compensatory development of shuttle trade, as well as an increase in the flow of Chinese goods via the East China Railroad. As a result, Zabaikalsk - a formerly small, closed military town - has become the main entry point for Chinese goods into Russia. Most of the local citizens are employed in customs and border services, the railway sector, budget sector, and shuttle trade. Frequent trips to Manzhouli and servicing the movement of people and goods across the border enable local people to survive. China has become for them a place of work along with a place of rest, shopping, and leisure.

\section{Life on 'the margin'}

Border practices and neighbourhood obviously have a direct and indirect effect on the social and economic development of these small border cities, and bring diversity to their life, distinguishing them from cities further away from the border. Even those residents who are not directly involved in cross-border movements, exchanges, and communications receive their share in border-related profits, which are redistributed from commuters to the closest members of their social circle as well as to other spheres of the local economy. Indeed, by defining the daily activities, the border provides a range of opportunities as well as risks and costs. Economic and social instability probably tip balance between opportunities and costs, especially when people consider the future of their children when defining their life strategies. If the city's border location neither increases prosperity nor improves the quality of life, and the neighbourhood is perceived predominantly in terms of risks, then the incentive to live there is reduced.

The respondents drew much attention to the numerous socio-economic problems of their cities. Among the problems listed were lack of work and low incomes, poverty, the low quality of medical services, inefficient urban governance, and corruption. In Armyansk, Dzhankoy, and Troitsk, inhabitants were also worried about increasing peripheralization and the closure of old industrial enterprises. As noted above, in Crimea people have pointed out especially positive changes, due to new trends of development and expectations on Russian assistance. Semantic tests used to identify the associations people held with regards to their place of residence (Fig. 4) show the correspondence of the above problems and negative definitions ('undeveloped', 'backward', 'poor', etc.). Positive definitions given to participants' own cities (e.g., 'beautiful', 'native,' 'green', 'ours', etc.), especially in the case of Troitsk, mostly indicate local patriotism and the attractiveness of the urban landscape. The prevalence of negative characteristics ascribed to Zabaikalsk appears to be related to the socio-economic contrasts across the border and a permanent comparison with neighbouring Manzhouli. While over the course of 25 years, the small town of Manzhouli has become a large city, with a population of 300,000, developed communications, skyscrapers, and night illumination, Zabaikalsk back on the Russian side of the border has remained a small peripheral town, separated from the regional capital by $500 \mathrm{~km}$ of uninhabited territory.

The massive exodus of young, active people in search of a better life correlates well with the majority share of negative definitions of Zabaikalsk, located far from the economically developed Russian centres. People in our case study cities choose mainly migrate to large and prosperous Russian cities, rather than neighbouring countries. This choice is indirectly confirmed by a positive perception of Russia (Fig. 5)' ${ }^{1}$, mainly based on statist patriotism and an emotional attachment to the Homeland.

The usage of projective methods also confirmed our thesis about the special attitude held by residents of small border cities to their country as a whole. People believe that 'the state and government' is exclusively responsible for the development of distant border territories. They feel entitled to border protection because they perceive their presence on the border as a defense agaisnt the territorial claims of their neighbours. Therefore, in their view, the state must provide them with a decent standard of living, to compensate for their burden of protecting the state border and enduring the risks associated with living in a distant border territory. Moreover, people believe that border areas need a special 'border status' that would better facilitate daily life and crossborder interactions with neighbours. However, locals also do not believe that they can actually affect decision-making by higher authorities regarding local development, foreign policy, international relations with neighbouring state, the border regime, and so on. 
Societal attitudes, hopes, and expectations that shape everyday life in the local border community almost correspond with the public mood in Russian society as a whole. The structure of fears negatively reflects the structure of a community's values. Our research shows that residents of small border cities are most afraid of losing their relatives, illness, poverty, unemployment, deterioration of relations with their neighbouring country, and especially war. According to a survey of the Levada Center in 2017, Russians' worst fears were illness among close relatives, poverty, and warfare (levada.ru 2017). The fear of illness is not a fear of any particular disease, but an expression (in a negative form) of that which is considered most essential: health. Fear of poverty reveals an inverted feeling of social and economic helplessness, and is a reflection of social vulnerability and insecurity. While fear of poverty was not one of the greatest fears of those living in small border cities, it is reflected in the concerns by Zabaikalsk residents about the need for survival. Lev Gudkov (1999) classifies these fears as those of unarticulated, background, uncertain anxiety and panic modes, which are connected with the level of stability of social ties and institutes in society. The fact that such diffuse fears are widespread across all our case studies indicates the strong sense of vulnerability in borderland communities, and explains why people express their hope for improvements in the socio-economic situation, living standards, level of wages, and stability.

\section{CONCLUSIONS}

The studies carried out at different sectors of the Russian border allow us to compare cross-border relationships and interactions with neighbours at the local level and the patterns of perception of neighbours on borders with different regimes and functions, as well as their impact on everyday life and people's well-being in conditions of local development deficit. Studying cities located directly on the border, the research aims to provide insights for understanding the conjunctions of different feelings and forms of proximity and distance, based on (un)familiarity, (un)similarity and (un)connectivity, with a national neighbourhood that reflects the (geo)political situation, level of cooperation, and relations between neighbouring countries, as well as socio-economic contrasts across the border. Such a complex construction helps to bring us closer to an understanding about the mutual interweaving of the state and the everyday life of ordinary individuals, as well as grassroots challenges to the territoriality of national borders and power relations.

Russian reality sometimes runs counter to theory. The considerable differences encountered at the RussiaChinese border do not restrain interactions. Yet the Chinese environment continues to be alien, despite the presence of Russian-language signs, the widespread use of pidgin, and intense interaction during cross-border shuttle trade. Russians simply do not feel comfortable in China. The different culture, lifestyle, and behavior of Chinese renders them 'Other' to those from neighbouring Russian cities. While the residents of border territories regularly cross the border, they participate in shuttle trade solely because they need to survive in the absence of other livelihood opportunities. Despite the numerous cases of fraud or deceit by Chinese dealers, residents of neighbouring territories still go to China in search of money.

The concepts of 'otherness' and 'strangeness' are confirmed by the situation in Northern Crimea; despite new trends, attitudes to people across the border have remained friendly, and such people are still perceived as 'Insiders'. On the border with Kazakhstan, although Kazakhs are still perceived as intimates, different nation-building processes and the long distances involved have increased the sense of difference and promoted the opinion of Kazakh neighbours as 'Strangers'.

Thus, institutional and social proximity on the border

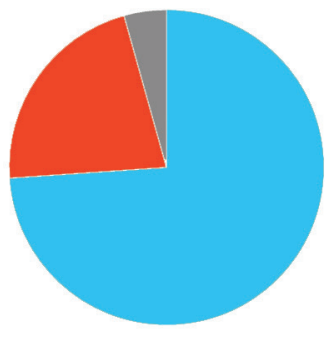

A)

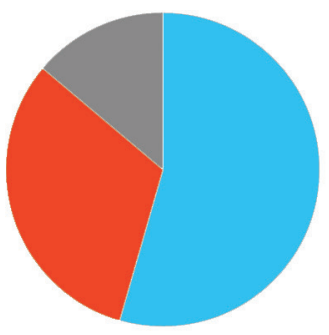

B)

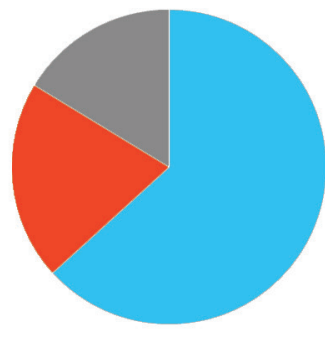

C)

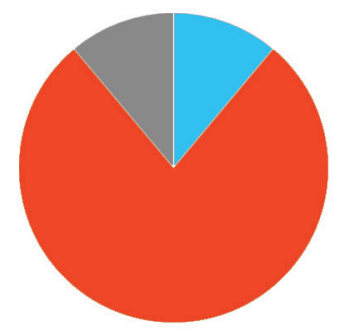

D)

POSITIVE

Negative

NeUtral

\section{Fig. 4. Characteristics ascribed to participants' city of residence (A: Armyansk; B: Dzhankoy; C: Troitsk; D: Zabaikalsk)}

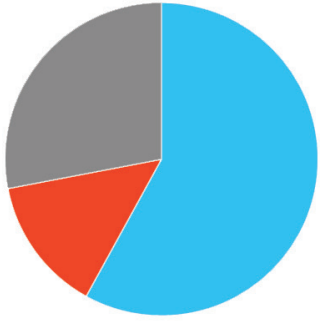

A)

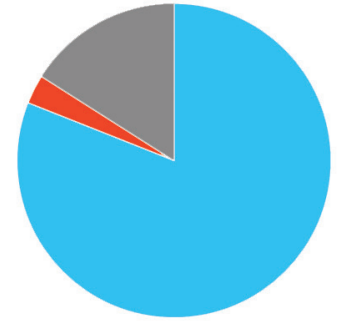

B)

Positive

Negative

NEUTRAL

Fig. 5. Characteristics ascribed to Russia in general (A:Troitsk; B: Zabaikalsk)

' Semantic tests to identify participants' associations with Russia were not conducted in Crimea. 
with Kazakhstan is neither necessary nor sufficient to the deepening of cross-border interaction. Despite the partnership and integration between countries, the intensity of border communications is less than expected. A low density of economic activities, poor infrastructure, and low population mobility still remain significant factors. Moreover, the simple lack of incentives to cross the boundary can play a much greater role than the obstacles that must be overcome to cross state borders. When motivation is weak, the abolition of barriers does not change anything (Zotova et al., 2018).

Despite lots of objective differences between the various sections of Russian borders, their subjective perceptions by people and social representations serve to unite them. Paying special attention to urban life during the focus groups has revealed that border towns are perceived primarily as a 'place of life'. Numerous everyday contacts with neighbours, including cross-border trips, force people to compare life here and there. The border is not considered anything extraordinary for the people living beside it, and any problems created by the border are perceived as secondary compared to the stagnation of urban development. Geographical distance and the low standard of living in small border cities promote the sense of abandonment, together with paternalism and a strong sense of frustration.

Local populations transfer the responsibility of their wellbeing to the government, because they believe that the state is required to provide them with a decent living for their important role as defenders of national borders. People expect that the Russian government will develop a well-balanced and comprehensive border policy; they hope border areas will receive a special status and the implementation of exclusive development programs. In the current socio-economic situation, in which 'the government does not provide an adequate standard of living', local populations are forced to use opportunities opened by the border and neighbouring state. That is why a potential border closure is perceived negatively as something that could undermine the last reason for living in the border city. Unfamiliarity, otherness, and significant differences between neighbouring territories are not allowed to get in the way of contact, because it is this contact that allows local residents to make a living.

\section{ACKNOWLEDGMENTS}

The research was supported by State Assignment IGRAS (0148-2019-0008, AAAA-A19-119022190170-1). Theoretical part of the article was prepared with partial support of the Immanuel Kant Baltic Federal University by the Russian Academic Excellence Project (5-100).

\section{REFERENCES}

Aure M. (2011). Borders of understanding: re-making frontiers in the Russian-Norwegian contact zone. Ethnopolitics, 2, 171-186.

Balogh P. (2013). Sleeping abroad but working at home: cross-border residential mobility between transnationalism and (re)bordering. Geografiska Annaler: Series B, Human Geography, 95(2), 189-204.

Boschma R. (2005). Proximity and innovation: A Critical assessment. Regional Studies, 39(1), 61-74.

Brambilla C. (2015). Exploring the critical potential of the borderscapes concept. Geopolitics, 1, 14-34.

Brazhalovich F.L., Kljuchnikov M.I., Kolosov V.A., Pavljuk S.G., Popov F.A. and Turov N.L. (2017). Life over the conflict borders: socioeconomic aspects of cross-border relations within divided cities (on the example of Bender and Dubossary). Izvestiya Rossiiskoi Akademii Nauk. Seria Geograficheskaya, 3, 45-57 (in Russian).

Dolińska K. and Niedźwiecka-Iwańczak N. (2017) German neighbours from across the river - Insiders? Strangers? Others? Social Studies, 1, 95-116.

Domaniewski S. and Studzińska D. (2016) The small border traffic zone between Poland and Kaliningrad region (Russia): The impact of a local visa-free border regime. Geopolitics, 21(3), 538-555.

Ghosh S. (2011). Cross-border activities in everyday life: the Bengal borderland. Contemporary South Asia, 19, 49-60.

Gudkov L. (1999). Fear as a frame of comprehension. Monitoring public opinion 1999, 6 (44), $46-53$.

Helleiner J. (2009). Young borderlanders, tourism work, and anti-Americanism in Canadian Niagara. Identities: global studies in culture and power, 16 (4), 438-462.

Houtum H. van (1999) The Geopolitics of Borders and Boundaries. Geopolitics 10(4), 672-679.

Koch K (2018). The spatiality of trust in EU external cross-border cooperation, European Planning Studies, 26(3), 591-610

Kolosov V.A. and Zotova M.V. (2019) China and Russian-Chinese relations in the mirror of Russian discourse. Problems of Geography, 148, 281-308 (in Russian).

Kozera B. (1999). «Stranger» and «Insider». Three reflections of an uninstrumental reason. In: Others insiders. Studies on ethnic issues. Katowice, 39-48.

Laine J. (2016). Threats, challenges, and Finnish-Russian cross-border security cooperation: a Finnish perspective tourism and geopolitics.

In: Derek Hall, ed., Tourism and geopolitics: issues and concepts from central and Eastern Europe, Wallingford, CAB International, 178-191. Levada.ru, (2015). Fears [online] Available at: www.levada.ru/2017/11/28/strahi-2/ [Accessed 20 Dec. 2019] (in Russian).

Newman D. and Paasi A. (1998). Fences and neighbours in the postmodern world: boundary narratives in political geography. Progress in Human Geography, 22 (2), 186-207.

Rippl S., Petrat A., Kindervater A. and Boehnke K. (2009). Transnational social capital: Are border regions a laboratory of social integration

in Europe? Berliner Journal für Soziologie, 19, 79-103.

Schack M. (2001). Regional identity in border regions: The difference borders make, Journal of Borderlands Studies, 16 (2), 99-114.

Scott J.W., Celata F., Coletti R. (2019). Bordering imaginaries and the everyday construction of the Mediterranean neighbourhood.

Introduction to the special issue European Urban and Regional Studies, 26(1), 3-8

Spierings B. and Velde M. van der (2013). Cross-Border Differences and Unfamiliarity: Shopping Mobility in the Dutch-German Rhine-

Waal Euroregion. European Planning Studies, 1, 5-23

Stoklosa K. (2013). The border in the narratives of the inhabitants of the German-Polish border region. In: European Border Regions in Comparison, 257-274.

Szytniewski B. and Spierings B. (2014). Encounters with Otherness: Implications of (Un)familiarity for Daily Life in Borderlands. Journal of Borderlands Studies, 29(3), 339-351. 
Szytniewski B., Spierings B. and Velde M. van der (2017). Socio-cultural proximity, daily life and shopping tourism in the Dutch-German border region. Tourism Geographies, 19(1), 63-77.

Timothy D. J. (1995). Political boundaries and tourism: Borders as tourist attractions, Tourism Management, 16(7), 525-532

Torre A. and Rallet A. (2005). Proximity and localization. Regional Studies, 39(1), 47-59.

Trippl M. (2010). Developing cross-border regional innovation systems: Key factors and chal- lenges. Tijdschrift voor Economische en Sociale Geografie, 101, 150-160.

Velde B. and van der Spierings B. (2008). Cross border shopping and the «bandwith of familiarity»: exploring the positive impact of national borders on consumer mobility in the Euregion Rhine, Nijmegen, Nijmegen School of Management.

Vendina O.I. and Kolosov V.A. (2007). Partnership to bypass barriers. In: Russia in global politics, 1, 142-154 (in Russian).

Zotova M., Gritsenko A. and Sebentsov A. (2018). Everyday Life in the Russian Borderlands: the motives and determinants of crossborder practices. Mir Rossii, 4, 56-77 (in Russian). 